\title{
Inclusion of lemon leaves and rice straw into compound feed and its effect on nutrient balance, milk yield, and methane emissions in dairy goats
}

\author{
T. Romero, ${ }^{1}$ I. Pérez-Baena, ${ }^{1}$ T. Larsen, ${ }^{2} \odot$ J. Gomis-Tena, ${ }^{3} \oplus$ J. J. Loor, ${ }^{4}{ }^{\oplus}$ and C. Fernández ${ }^{1 *} \oplus$ \\ ${ }^{1}$ Instituto de Ciencia y Tecnología Animal, Universitat Politècnica de València, 46022 Valencia, Spain \\ ${ }^{2}$ Animal Science Department, Aarhus University, 8830 Tjele, Denmark \\ ${ }^{3}$ Centro de Investigación e Innovación en Bioingeniería, Universitat Politècnica de Valencia, 46022 Valencia, Spain \\ ${ }^{4}$ Department of Animal Sciences, Division of Nutritional Sciences, University of Illinois, Urbana 61801
}

\begin{abstract}
The objective of this experiment was to study the effects of incorporating lemon leaves and rice straw into the compound feed of diets for dairy goats. Ten Murciano-Granadina dairy goats ( $\mathrm{n}=5$ per group $)$ in mid-lactation were used in a crossover design experiment ( 2 treatments across 2 periods). Goats were fed a mixed ration with barley grain (control, $\mathrm{CON}$ ) or $\mathrm{CON}$ plus lemon leaves $[189 \mathrm{~g} / \mathrm{kg}$ of dry matter $(\mathrm{DM})]$ and rice straw $(120 \mathrm{~g} / \mathrm{kg}$ of $\mathrm{DM})$ in place of barley grain (LRS). Soybean oil $(19 \mathrm{~g} / \mathrm{kg}$ of DM) was added to the LRS diet to make it isoenergetic (17 MJ of gross energy $/ \mathrm{kg}$ of DM) relative to CON. After $14 \mathrm{~d}$ on their respective treatments, goats were allocated to individual metabolism cages for another $7 \mathrm{~d}$. Subsequently, feed intake, total fecal and urine output, and milk yield were recorded daily over the first $5 \mathrm{~d}$. During the last $2 \mathrm{~d}$, ruminal fluid and blood samples were collected, along with individual gas exchange measurements recorded by a mobile open-circuit indirect calorimetry system using a head box. No differences in DM intake were detected, and ME intake in LRS was lower than in CON (1,095 vs. $1,180 \mathrm{~kJ} / \mathrm{kg}$ of metabolic body weight). No differences were observed in milk production, but milk fat content was greater in LRS $(6.4 \%)$ than in CON $(5.6 \%)$. Greater concentrations of monounsaturated (14.94 vs. $11.96 \mathrm{~g} / 100 \mathrm{~g}$ of milk fat) and polyunsaturated fatty acids ( 4.53 vs. $4.03 \mathrm{~g} / 100 \mathrm{~g}$ of milk fat) were detected in the milk of goats fed LRS compared with CON. Atherogenicity (2.68 vs.1.91) and thrombogenic (4.58 vs. 2.81) indices were lower with LRS compared with CON. Enteric $\mathrm{CH}_{4}$ emission was lower in LRS $(24.3 \mathrm{~g} / \mathrm{d})$ compared with CON $(31.1 \mathrm{~g} / \mathrm{d})$, probably due to the greater lipid content and unsaturated fatty acid profile of lemon leaves and the soybean oil added in
\end{abstract}

Received January 7, 2020.

Accepted February 26, 2020.

*Corresponding author: cjfernandez@dca.upv.es the LRS diet. Overall, data suggest that incorporating lemon leaves and rice straw into lactating goat diets is effective in reducing $\mathrm{CH}_{4}$ emissions while allowing improvements in milk fat production and milk thrombogenic index without affecting production performance. Thus, their inclusion in compound feeds fed to small ruminants appears warranted and would have multiple positive effects, as on efficiency of nutrient use, human health, and the environment.

Key words: dairy goat, energy, lemon leaves, methane emission, rice straw

\section{INTRODUCTION}

Human activities, including economic, energy, technological, and environmental processes, are important contributors to climate change. In fact, these are also recognized as primary factors affecting the sustainability of livestock production systems (Zheng et al., 2019). Among environmental activities that contribute toward climate change, flooding cultivated rice soil and then disposal of crop residues (rice straw field burning) by the agricultural sector is a major source of $\mathrm{CH}_{4}$ emissions. Rice is the world's third largest cereal crop, after corn and wheat, but produces the largest amount of crop residues (Van Soest, 2006). Spain produces $525,504 \mathrm{t} / \mathrm{yr}$ of rice straw, with its use in ruminant diets being an alternative to recycling it.

Total world citrus production averages 116 million $\mathrm{t} /$ yr (FAOSTAT, 2019), with pruning waste representing the main residue generated during cultivation (Bampidis and Robinson, 2006). Yearly, Spain generates 1.87 million $\mathrm{t}$ of pruning waste (DM basis), of which approximately $50 \%$ is leaf and $50 \%$ wood (EFEAGRO, 2016). Within Spain, the Community of Valencia is one of the world's oldest citrus production areas, and due to the high production of lemons, their leaves are an important pruning waste.

Plant extracts offer a unique opportunity toward developing alternatives to reduce $\mathrm{CH}_{4}$ emissions, as many plants produce secondary metabolites such as 
saponins and tannins, which have antimicrobial properties. Similarly, the well-documented antimicrobial activities of essential oils and their active components have prompted examination of the potential of these secondary metabolites to manipulate rumen microbial fermentation to reduce gas emissions and improve production efficiency (Calsamiglia et al., 2007; Patra and Yu, 2012; Knapp et al., 2014).

Lemon leaves are rich in essential oils, and essential oils can interact with rumen microbial cell membranes and inhibit methanogenesis (Calsamiglia et al., 2007). Due to the higher lipid content and the essential oils present in citrus leaves, lemon leaves could be beneficial to reduce $\mathrm{CH}_{4}$ emissions from ruminants, in part because of the negative effect of oil on $\mathrm{CH}_{4}$ emissions (Patra and Yu, 2012).

Considering the large amounts of rice straw and citrus leaves produced annually all over the world and their potential pollution capacity, especially when burned, the revalorization and reutilization of these by-products as complementary feed sources for livestock is a relevant subject in the exploration of the circular economy combining agriculture and livestock. To demonstrate that using lemon leaves and rice straw in livestock is a suitable strategy to recycle, reuse, and reduce $\mathrm{CH}_{4}$ emissions, it is necessary to maintain animal performance. Therefore, the objective of the present study was to include lemon leaves and rice straw as by-products replacing cereal grain in a commercial compound feed for lactating goats. Feed intake, energy, carbon and nitrogen balance, milk performance, and $\mathrm{CH}_{4}$ emissions were measured to assess performance.

\section{MATERIALS AND METHODS}

The experimental procedures were approved (2017/ VSC/PEA/00182) by the Committee on Animal Use and Care at the Polytechnic University of Valencia (Valencia, Spain), and followed the codes of practice for animals used in experimental work proposed by the EU (European Union, 2003). The authors declare that this experiment did not involve ethical issues or affect any endangered or protected species.

\section{Animals and Diets}

The experiment was conducted at the Animal Science Department Experimental Farm of the Polytechnic University of Valencia. Ten multiparous mature Murciano-Granadina dairy goats in mid-lactation were selected and divided into 2 homogeneous groups of 5 each, based on similar BW $(47.3 \pm 0.07 \mathrm{~kg}$ of $\mathrm{BW}$; values are $\pm \mathrm{SD}$ ), milk production in the previous lactation $(650.3 \pm 42 \mathrm{~kg}$ of milk per $210 \pm 30 \mathrm{~d}$ of lactation, on average). Treatments were evaluated in a crossover design ( 2 treatments crossed with 2 periods) using diets fed as TMR (Table 1). Intake was ad libitum, with diets offered at $110 \%$ of consumption relative to the preceding day; thus, goats received daily a TMR with $1 \mathrm{~kg}$ of alfalfa hay and $1.7 \mathrm{~kg}$ of concentrate (37:63 forage-toconcentrate ratio). The concentrate and premix were mixed and pelleted. The control (CON) group was fed concentrate with $406 \mathrm{~g} / \mathrm{kg}$ of DM of barley grain, and the test group (LRS) was fed concentrate in which 300 $\mathrm{g}$ of lemon leaves $/ \mathrm{kg}$ of DM and $190 \mathrm{~g}$ of rice straw $/ \mathrm{kg}$ of DM replaced barley grain. Nutrient requirements followed the recommendation of Calsamiglia et al. (2009) for lactating goats fed mixed rations (1.6 Mcal of $\mathrm{NE}_{\mathrm{L}}$ / $\mathrm{kg}$ of $\mathrm{DM}$ and $95 \mathrm{~g}$ of $\mathrm{MP} / \mathrm{kg}$ of $\mathrm{DM})$. To achieve isoenergetic diets, soybean oil was added to the LRS diet. The chemical composition of alfalfa, concentrates, and whole mixed diet (forage and pelleted concentrate) is reported in Table 1 and diet fatty acids (FA) in Table 2. Half the daily ration was offered at $0800 \mathrm{~h}$ and half at $1600 \mathrm{~h}$. Goats had free access to water.

\section{Experimental Schedule and Measurements}

Apparent total-tract digestibility, gas exchange, energy partitioning, $\mathrm{C}$ and $\mathrm{N}$ balance, oxidation of nutrients, and milk composition and yield were determined. The experiment had two 33-d periods. During the adaptation period, goats were fed the experimental diet in pens for $14 \mathrm{~d}$ and then allocated to individual metabolism cages at thermoneutrality $\left(20\right.$ to $23^{\circ} \mathrm{C}$, determined by a HOBO probe; Onset Computer Corporation, Bourne, MA) for another $7 \mathrm{~d}$. Next, data on feed offered and refused and total fecal, urine, and milk output were recorded daily for each goat during a 5 -d period. In addition, BW at the beginning and end of the experimental period was recorded. Feces were collected in wire-screen baskets placed under the floor of the metabolism crates, and urine was collected through a funnel into plastic buckets containing $100 \mathrm{~mL}$ of $10 \%$ ( vol/vol) $\mathrm{H}_{2} \mathrm{SO}_{4}$. The acidification of urine was necessary to prevent microbial degradation and loss of volatile ammonium. Representative samples (10\%) of diet, feces, and urine were collected over 5 consecutive days, stored at $-20^{\circ} \mathrm{C}$, and pooled for chemical analysis.

Goats were milked once daily at $0800 \mathrm{~h}$ with a portable milking machine (Flaco, model DL-170, J. Delgado S.A., Ciudad Real, Spain). Immediately after milking, individual milk yield was measured and a subsample placed in a bottle and frozen until analysis. In addition, samples were collected into plastic vials that contained $20 \mathrm{mg}$ of potassium dichromate as a preservative and taken to the Interprofessional Dairy Laboratory of the Valencia Community Region (Valencia, Spain) for com- 
position analysis (DM, CP, fat, and lactose). Before gas exchange determinations, goats were moved from metabolism cages to pens for $2 \mathrm{~d}$, during which ruminal fluid and blood samples were collected. Ruminal fluid samples were collected via stomach tube before the morning feeding, following the procedure described by Ramos-Morales et al. (2014). Ruminal fluid was strained through 4 layers of cheesecloth and $\mathrm{pH}$ determined immediately, using a portable $\mathrm{pH}$ meter (Model 265A, Orion Research Inc., Beverly, MA). A subsample of ruminal fluid was acidified with $50 \% \mathrm{H}_{2} \mathrm{SO}_{4}$ and frozen until later determination of ammonium. Samples for analysis of VFA were mixed with $\mathrm{H}_{3} \mathrm{PO}_{4}$ and kept frozen until analysis. Jugular blood was sampled in 10-mL tubes treated with EDTA and immediately centrifuged for plasma separation and storage at $-20^{\circ} \mathrm{C}$.

Gas exchange was measured for each goat during 24 $\mathrm{h}$ using an indirect calorimetric system based on 2 ventilated head boxes designed for small ruminants. The respirometry system was equipped with 2 head hoods, 2 flow meters (Thermal Mass Flowmeter Sensyflow
VT-S, ABB, Alzenau, Germany), and 2 air suctions provided by centrifugal fans (CST60 Soler Palau Inc., Parets del Vallès, Barcelona, Spain). Concentrations of $\mathrm{CH}_{4}$ and $\mathrm{CO}_{2}$ were measured using the infrared principle and $\mathrm{O}_{2}$ measured with the paramagnetic principle (Easyflow Gas Analyzer, model 3020, ABB). Although the unit was an autocalibrated model, the analyzers were calibrated with reference gases before each test. Fernández et al. (2012, 2015, 2019a) described the mobile open-circuit respirometry system used for these measurements. The whole system was calibrated by injecting pure $\mathrm{N}_{2}$ and $\mathrm{CO}_{2}$ into the head box (McLean and Tobin, 1987), determined gravimetrically using a precision scale (MOBBA mini-SP $0.2-30 \mathrm{~kg}$, Industrial Weighing System, Barcelona, Spain). Calibration factors were calculated according to Brockway et al. (1971). The $\mathrm{CH}_{4}$ and $\mathrm{CO}_{2}$ production and $\mathrm{O}_{2}$ consumption were calculated as described by Aguilera and Prieto (1986). An initial atmospheric air sample was collected, and the gas concentrations were used as reference for calculations.

Table 1. Ingredients and chemical composition of the diets

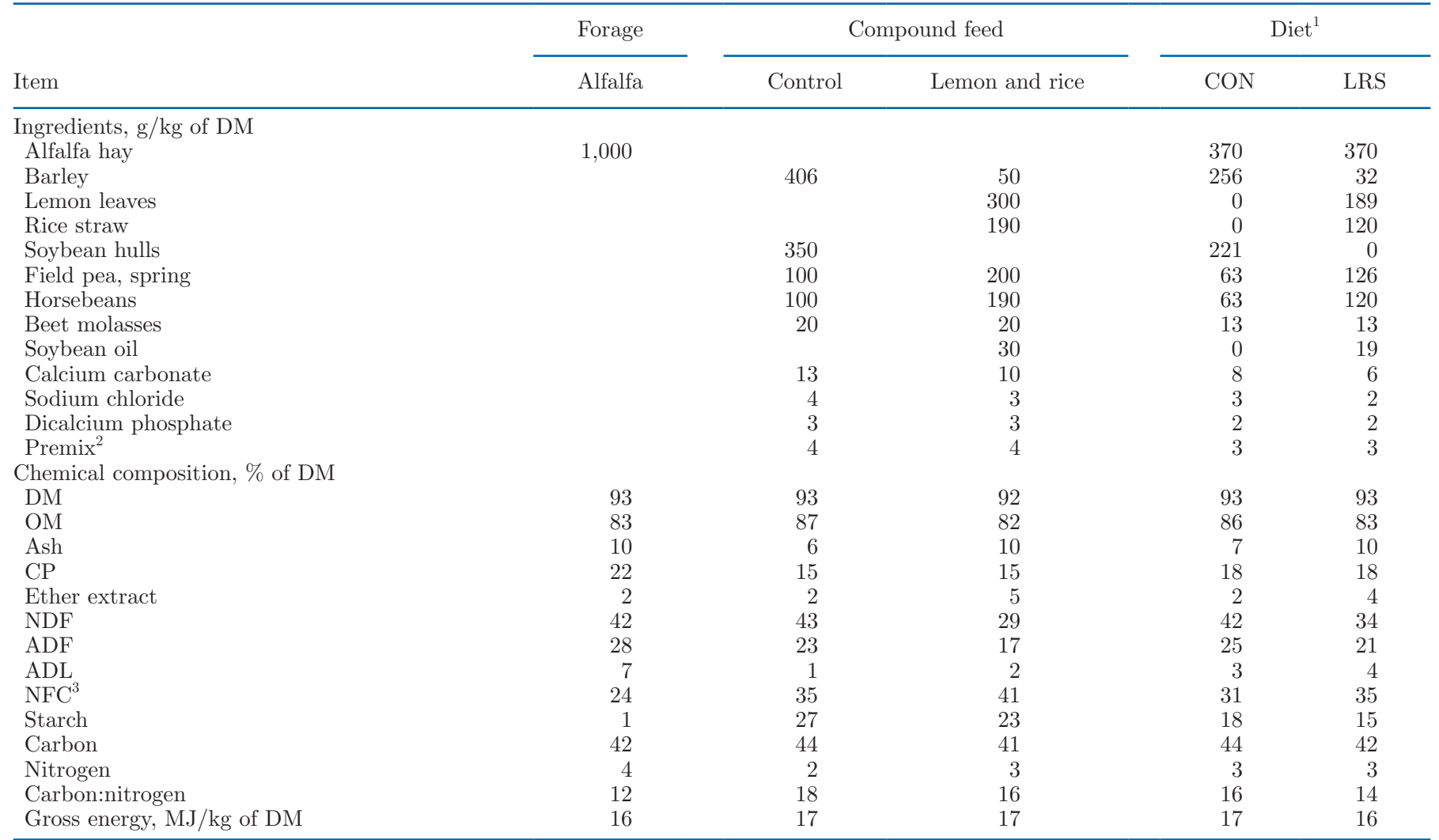

${ }^{1} \mathrm{CON}=$ control; LRS $=$ lemon leaves and rice straw.

${ }^{2}$ Provided by NACOOP SA (Madrid, Spain). Premix composition (mg/kg or IU/kg of premix): Se, 40; I, 250; Co, 80; Cu, 3,000; Fe, 6,000; Zn, 23,400; Mn, 29,000; S, 60,000; Mg, 60,000; vitamin A, 2,000,000 IU; vitamin $\mathrm{D}_{3}$, 400,000; vitamin E, 2,000 mg/kg; nicotinic acid, 10,000; choline, 20,300 .

${ }^{3} \mathrm{NFC}=100-(\mathrm{NDF}+$ ash $+\mathrm{CP}+$ ether extract $)$. 


\section{Chemical Analysis}

Feed, feed refusal, and feces samples were first dried in a forced-air oven at $55^{\circ} \mathrm{C}$ for $48 \mathrm{~h}$ and then ground to pass a 1-mm screen before analysis. Urine and milk were lyophilized before analysis. Chemical analyses of the diet, refusals, and feces were conducted according to AOAC International (2000) for DM (934.01), ash (942.05), and ether extract (EE; 920.39). The DM of diets and feces was determined by oven-drying at 102 $\pm 2^{\circ} \mathrm{C}$ for $24 \mathrm{~h}$. Ash concentration was measured by incineration in an electric muffle furnace at $550^{\circ} \mathrm{C}$ for $6 \mathrm{~h}$. The EE was extracted with petroleum ether after acid hydrolysis to recover saponified fat (Soxhlet System HT Tecator, Foss Analytics, Hillerød, Denmark; 1047 Hydrolyzing Unit and 1043 Extraction Unit). The $\mathrm{NDF}$ and ADF were measured in an ANKOM Fiber Analyzer (A220, ANKOM Technology, Macedon, NY) according to Mertens (2002) and AOAC International (2000), respectively. The NDF was determined using sodium sulfite and $\alpha$-amylase. The NFC content of diets was calculated using the difference method based on chemical analysis of individual feeds according to NRC (2001): NFC $=100-$ NDF - ash $-\mathrm{CP}-\mathrm{EE}$. The gross energy $(\mathbf{G E})$ content of the dried samples (feed,

Table 2. Fatty acid profile (g/100 g of oil) of experimental diets ${ }^{1}$

\begin{tabular}{|c|c|c|}
\hline Item & $\mathrm{CC}$ & LR \\
\hline C6:0 & 0.102 & 0.204 \\
\hline C8:0 & 0.040 & 0.026 \\
\hline $\mathrm{C} 12: 0$ & 0.031 & 0.127 \\
\hline C14:0 & 0.447 & 0.020 \\
\hline C15:0 & 0.117 & 0.100 \\
\hline C16:0 & 22.67 & 16.84 \\
\hline C16:1 & 0.210 & 0.145 \\
\hline C17:0 & 0.335 & 0.290 \\
\hline C17:1 & 0.085 & 0.075 \\
\hline C18:0 & 4.480 & 4.449 \\
\hline C18:1n-9 trans & 0.067 & 0.028 \\
\hline C18:1n-9 cis & 17.55 & 24.62 \\
\hline C18:1n-7 & 2.581 & 0.000 \\
\hline $\mathrm{C} 18: 2 \mathrm{n}-6$ cis & 44.06 & 42.72 \\
\hline C20:0 & 0.502 & 0.459 \\
\hline C18:3n-6 & 0.011 & 0.117 \\
\hline C20:1 & 0.467 & 0.278 \\
\hline C18:3n-3 & 4.598 & 6.886 \\
\hline $\mathrm{C} 20: 2$ & 0.020 & 0.178 \\
\hline $\mathrm{C} 22: 0$ & 0.421 & 0.484 \\
\hline C20:3n-6 & 0.000 & 0.090 \\
\hline C22:1n-9 & 0.197 & 0.195 \\
\hline C20:3n-3 & 0.129 & 0.124 \\
\hline $\mathrm{C} 22: 2$ & 0.059 & 0.087 \\
\hline $\mathrm{C} 24: 0$ & 0.284 & 0.348 \\
\hline C20:5n-3 eicosapentaenoic acid & 0.402 & 0.471 \\
\hline C22:4n-6 & 0.052 & 0.051 \\
\hline
\end{tabular}

${ }^{1} \mathrm{CC}=$ control compound feed without forage; $\mathrm{LR}=$ compound feed with lemon leaves and rice straw without forage. feces, urine, and milk) was analyzed by combustion in an adiabatic bomb calorimeter (Autobomb, Gallenkamp, Loughborough, UK). Starch content was determined by an enzymatic method ( $\alpha$-amylase obtained from Sigma-Aldrich, Steinheim, Germany) according to Batey (1982). The C and N were analyzed through the Dumas principle (TruSpec CN; Leco Corp., St. Joseph, $\mathrm{MI})$. Multiplying $\mathrm{N}$ by a factor of 6.25 converted the results to CP.

Determination of ruminal VFA was based on the method described by Jouany (1982) using a gas chromatograph (Fisons 8000 series; Fisons Instruments SpA, Milan, Italy) equipped with a split/splitless injector and flame ionization detector. Milk composition (fat, protein, lactose, citrate, and total milk solids content) was analyzed using an infrared analyzer (MilkoScan FT120, Foss Analytics). Fatty acid methyl esters of milk and diet lipids were prepared directly as previously described by O'Fallon et al. (2007). The FAME were analyzed in a Focus Gas Chromatograph (Thermo Fisher Scientific, Milan, Italy) equipped with a split/splitless injector and a flame ionization detector. Separation of methyl esters was performed in a fused silica capillary column (SP 2560, Supelco, Bellefonte, PA; $100 \mathrm{~m} \times 0.25 \mathrm{~mm} \times 0.2-\mu \mathrm{m}$ film thickness). The carrier gas was helium at a linear velocity of $20 \mathrm{~cm} / \mathrm{s}$. The samples were injected with a split ratio of $1 / 100$. The initial oven temperature was set at $140^{\circ} \mathrm{C}$, held for $5 \mathrm{~min}$, increased to $240^{\circ} \mathrm{C}$ at $4^{\circ} \mathrm{C} / \mathrm{min}$, and finally maintained at that temperature for $30 \mathrm{~min}$. Both detector and injector temperatures were set at $260^{\circ} \mathrm{C}$.

Metabolites in ruminal fluid, urine, blood plasma, and milk were analyzed. Briefly, glutamine, glutamate, and free amino groups were determined according to Larsen and Fernández (2017). Urine and plasma ammonium, total protein, urea, uric acid, albumin, creatinine, L-lactate, and glucose were analyzed according to standard procedures (Siemens Diagnostics Clinical Methods for ADVIA 1800; Siemens Healthcare GmbH, Erlangen, Germany). Plasma nonesterified fatty acids (NEFA) were determined using the NEFA C Acyl-CoA synthetase-Acyl-CoA oxidase (ACS-ACOD) assay method, and BHB was determined as proposed by Harano et al. (1985). Both nonesterified fatty acids and BHB analyses were performed on the ADVIA 1800 System (Siemens Healthcare). Minor milk constituents such as glucose and glucose-6-phosphate (Larsen, 2015), isocitrate (Larsen, 2014), BHB (Larsen and Nielsen, 2005), and uric acid (Larsen and Moyes, 2010) were determined via enzymatic-fluorometric methods. Milk urea was analyzed using flow injection analysis and enzymatic degradation. Application notes from the manufacturer were followed (Foss Analytics). 


\section{Calculations}

The ME intake (MEI) was calculated as the difference between GE intake and energy losses in feces (digestible energy), urine, and $\mathrm{CH}_{4}$ (with an energy equivalent value of $39.5 \mathrm{~kJ} / \mathrm{L}$ of $\mathrm{CH}_{4}$; Brouwer, 1965).

Heat production (HP) was determined from measurements of $\mathrm{O}_{2}$ consumption, $\mathrm{CO}_{2}$ and $\mathrm{CH}_{4}$ production, and urine $\mathrm{N}$ ( $\left.\mathbf{N}_{\text {urine }}\right)$, using the equation of Brouwer (1965):

$$
\begin{aligned}
\mathrm{HP}(\mathrm{kJ})= & 16.18 \times \mathrm{O}_{2}+5.02 \times \mathrm{CO}_{2}-2.17 \\
& \times \mathrm{CH}_{4}-5.99 \times \mathrm{N}_{\text {urine }}
\end{aligned}
$$

where gases were expressed in liters per day and $\mathrm{N}_{\text {urine }}$ in grams per day. The net energy was the difference between ME and HP. The tissue energy was calculated as the difference between net energy and milk energy.

The energy associated with the oxidation of protein (OXP), oxidation of carbohydrate (OXCHO), and oxidation of fat (OXF) was calculated using the methods of Brouwer (1958) and Chwalibog et al. (1997) for ruminants. The $\mathrm{CO}_{2}$ production from oxidation $\left(\mathbf{C O}_{2 \mathrm{x}}\right)$ was calculated as $\mathrm{CO}_{2}-\left(2 \times \mathrm{CH}_{4}\right)$, according to Fahey and Berger (1988). The calculations were carried out as follows:

$$
\begin{gathered}
\mathrm{OXP}=6.25 \times \mathrm{N}_{\text {urine }} \times 18.42(\mathrm{~kJ} / \mathrm{g}) \\
\mathrm{OXCHO}=\left(-2.968 \times \mathrm{O}_{2}+4.174 \times \mathrm{CO}_{2 \mathrm{x}}\right. \\
\left.-2.446 \times \mathrm{N}_{\text {urine }}\right) \times 17.58(\mathrm{~kJ} / \mathrm{g}) \\
\mathrm{OXF}=\left(1.719 \times \mathrm{O}_{2}-1.719 \times \mathrm{CO}_{2 \mathrm{x}}-1.963 \times \mathrm{N}_{\text {urine }}\right) \\
\times 39.76(\mathrm{~kJ} / \mathrm{g})
\end{gathered}
$$

Then the HP from oxidation $(\mathbf{H P x})$ was

$$
\begin{aligned}
\operatorname{HPx}(\mathrm{kJ})= & 16.18 \times \mathrm{O}_{2}+5.02 \times \mathrm{CO}_{2 \mathrm{x}} \\
& -5.99 \times \mathrm{N}_{\text {urine }} .
\end{aligned}
$$

Again, gases were expressed in liters per day and $\mathrm{N}_{\text {urine }}$ in grams per day. Heat of fermentation was estimated by subtracting HP from HPx. The nonprotein respiratory quotient from oxidation of nutrients (RQnpx) was determined as follows: $\mathrm{RQnpx}=\left[\mathrm{CO}_{2 \mathrm{x}}-\left(\mathrm{N}_{\text {urine }} \times 6.25\right.\right.$ $\times 0.774)] /\left[\mathrm{O}_{2}-\left(\mathrm{N}_{\text {urine }} \times 6.25 \times 0.957\right)\right]$. For $\mathrm{C}$ and $\mathrm{N}$ balance, we followed the equations and values proposed by McLean and Tobin (1987), and retained protein and fat, in grams, were calculated.

The efficiency of ME for milk and maintenance $(\mathrm{kls})$ was calculated according to INRA (2018): $\mathrm{kls}=0.65+$
$0.247 \times(q-0.63)$, with $q$ being the metabolizability (ME/GE).

\section{Statistical Analysis}

The effects of diet on intake, digestibility, ruminal fermentation, milk performance, energy, $\mathrm{C}$ and $\mathrm{N}$ balances, and oxidation of nutrients were analyzed using a mixed model (lme function from the nlme library) in $\mathrm{R}$ (R Core Team, 2016). The experiment was conducted as a crossover design: each goat received both treatments in 2 periods. The following statistical model was used: $\mathrm{Y}=\mu+\mathrm{D}+\mathrm{T}+$ goat $+\varepsilon$, where $\mathrm{Y}$ is the dependent variable, $\mu$ is the overall mean, $\mathrm{D}$ and $\mathrm{T}$ are the fixed effects of diet and period of time, respectively, goat is the random effect of goat, and $\varepsilon$ is the random error. Least squares means were reported throughout, and differences were considered significant at $P<0.05$.

\section{RESULTS AND DISCUSSION}

No significant effect was observed for period of time in the crossover design; thus, tables report only the effect of diet. The average values for the calibration factors were $1.0022 \pm 0.00111(\mathrm{n}=4), 0.9911 \pm 0.00913$ $(\mathrm{n}=4)$, and $0.9712 \pm 0.00557(\mathrm{n}=4)$ for $\mathrm{O}_{2}, \mathrm{CO}_{2}$, and $\mathrm{CH}_{4}$, respectively.

\section{Feed Intake, Digestibility, and Ruminal Fermentation}

No difference in DMI $(P>0.05)$ was observed between diets $(2.0 \mathrm{~kg} / \mathrm{d}$, on average), with the same amount of concentrate consumed by each group. Differences $(P<0.05)$ were detected for apparent digestibility of DM, OM, NDF, ADF, and energy, with lower values in LRS compared with CON. However, greater values $(P<0.05)$ for $\mathrm{CP}$ and $\mathrm{EE}$ digestibility were observed in LRS compared with CON. The higher barley content and lower EE in the CON compared with the LRS diet (essential oil content in lemon leaves and soybean oil added to the diet) likely explains the greater apparent digestibility: EE was $2 \%$ in CON, compared with $4 \%$ in LRS. Classical work from Palmquist and Jenkins (1980) indicated that high dietary lipid is more likely to inhibit fiber degradability with a concomitant reduction in fermentation, possibly due to coating food particles and preventing bacterial attachment. Average ruminal pH never fell below 6.2 (Table 3), suggesting that values obtained were sufficiently high to maintain normal ruminal fermentation (Ørskov and Fraser, 1975). Although stomach tube is a suitable noninvasive technique for ruminal fluid sampling, it is prone to saliva contamination, which would raise the $\mathrm{pH}$ in 
Table 3. Intake, apparent digestibility coefficients (\% of DM), and ruminal fermentation of MurcianoGranadina goats $(\mathrm{n}=10)$ during mid-lactation according to type of diet

\begin{tabular}{|c|c|c|c|c|}
\hline \multirow[b]{2}{*}{ Item } & \multicolumn{2}{|c|}{ Diet $^{1}$} & \multirow[b]{2}{*}{ SEM } & \multirow[b]{2}{*}{$P$-value } \\
\hline & $\mathrm{CON}$ & LRS & & \\
\hline DMI, kg/d & 2.00 & 2.04 & 0.022 & 0.52 \\
\hline Concentrate DMI, kg/d & 1.52 & 1.52 & 0.012 & 0.64 \\
\hline Forage DMI, $\mathrm{kg} / \mathrm{d}$ & 0.49 & 0.51 & 0.022 & 0.64 \\
\hline \multicolumn{5}{|c|}{ Apparent total-tract digestibility } \\
\hline $\mathrm{DM}$ & 69.0 & 63.6 & 0.58 & 0.001 \\
\hline $\mathrm{OM}$ & 71.1 & 66.0 & 0.55 & 0.001 \\
\hline $\mathrm{CP}$ & 67.1 & 71.5 & 0.57 & 0.001 \\
\hline Ether extract & 53.3 & 76.4 & 1.55 & 0.001 \\
\hline $\mathrm{NDF}$ & 60.4 & 41.5 & 1.31 & 0.001 \\
\hline $\mathrm{ADF}$ & 53.3 & 37.5 & 1.28 & 0.001 \\
\hline $\mathrm{NFC}^{2}$ & 90.5 & 89.7 & 0.43 & 0.32 \\
\hline Energy & 69.8 & 65.3 & 0.54 & 0.001 \\
\hline \multicolumn{5}{|l|}{ Rumen fermentation } \\
\hline $\mathrm{pH}$ & 6.98 & 7.08 & 0.041 & 0.20 \\
\hline Total VFA, $\mathrm{m} M$ & 36.9 & 34.1 & 2.75 & 0.621 \\
\hline \multicolumn{5}{|l|}{ Individual VFA, $\mathrm{m} M$} \\
\hline Acetic acid & 22.8 & 21.4 & 1.84 & 0.72 \\
\hline Propionic acid & 5.35 & 5.27 & 0.497 & 0.94 \\
\hline Isobutyric acid & 0.50 & 0.58 & 0.027 & 0.10 \\
\hline Butyric acid & 7.03 & 5.37 & 0.570 & 0.15 \\
\hline Isovaleric acid & 0.69 & 0.86 & 0.034 & 0.008 \\
\hline Valeric acid & 0.50 & 0.53 & 0.034 & 0.67 \\
\hline Caproic acid & 0.06 & 0.04 & 0.026 & 0.06 \\
\hline
\end{tabular}

${ }^{1} \mathrm{CON}=$ control; LRS $=$ lemon leaves and rice straw.

${ }^{2} \mathrm{NFC}=100-(\mathrm{NDF}+\mathrm{ash}+\mathrm{CP}+$ ether extract $)$.

the sample (Ramos-Morales et al., 2014). Despite the greater amount of concentrate used to feed goats in this trial, the amount of total VFA was low $(35.5 \mathrm{mM}$, on average) compared with the results of other studies. For instance, Romero-Huelva and Molina-Alcaide (2013) found average values of $66.9 \mathrm{mM}$ among rumenfistulated Murciano-Granadina goats fed alfalfa hay and concentrate in a 1:1 ratio. This suggested that ruminal fluid collection through stomach tube did not yield a representative total VFA. Other than isovaleric acid, no differences were detected for total and individual VFA. Because isovaleric acid is mainly generated during degradation of branched-chain amino acids, the greater $(P=0.008)$ concentration of this VFA observed in goats fed LRS suggested greater ruminal protein degradation. Furthermore, this response might indicate an inefficient use of amino groups for ruminal protein synthesis (Casper et al., 1999).

\section{Energy Balance and Oxidation of Nutrients}

Despite similar DMI, no significant differences $(P$ $>0.05)$ were observed for GE intake $(1,926 \mathrm{~kJ} / \mathrm{kg}$ of $\mathrm{BW}^{0.75}$, on average; Table 4). The lower digestibility $(P=0.001)$ in the LRS diet indicated greater energy losses in feces. Urine energy losses were greater $(P<$ 0.05) in LRS compared with CON, suggesting that the greater content of EE in the LRS diet might have reduced microbial protein synthesis. This effect might partly explain the reduction $(P=0.001)$ in energy losses as $\mathrm{CH}_{4}$ (95 vs. $75 \mathrm{~kJ} / \mathrm{kg}$ of $\mathrm{BW}^{0.75}$ for $\mathrm{CON}$ and LRS, respectively) with the LRS diet, supporting the negative effect of lipids in the diet on $\mathrm{CH}_{4}$ production (Knapp et al., 2014).

Due to greater losses in feces and urine with the LRS diet, MEI was lower $(P=0.023)$ with LRS $(-85 \mathrm{~kJ} / \mathrm{kg}$ of $\left.\mathrm{BW}^{0.75}\right)$. Although lower tissue energy was detected in LRS compared with CON $\left(-103 \mathrm{~kJ} / \mathrm{kg}\right.$ of $\left.\mathrm{BW}^{0.75}\right)$, no differences between treatments were observed for $\mathrm{HP}\left(584 \mathrm{~kJ} / \mathrm{kg}\right.$ of $\mathrm{BW}^{0.75}$, on average) and milk energy (432 kJ $/ \mathrm{kg}$ of $\mathrm{BW}^{0.75}$, on average). In lactating animals, lipogenic nutrients can increase the partitioning of ME into milk (increasing milk fat yield) and consequently decrease the partitioning of ME into body reserves (van Knegsel et al., 2007). Thus, the present observations suggest that the lower content of glucogenic nutrients in LRS (i.e., the CON diet was higher in barley grain) did not favor body fat deposition and partitioning of ME into body tissue.

The efficiency of ME for milk and maintenance is defined as kls by INRA (2018); following this approach, the efficiencies for the CON and LRS diets were 0.65 and 0.63 , respectively, and no significant differences were observed between diets. Aguilera et al. (1990) and Tovar-Luna et al. (2010) reported similar values $(0.67$ and 0.63 , respectively). 
The pattern of energy utilization, when expressed as megajoules per day, did not differ between treatments for GE intake and digestible energy ( 35 and $24 \mathrm{MJ} / \mathrm{d}$, respectively). However, the MEI differences between diets remained, with consumption of ME in CON being greater relative to LRS. When energy balance was expressed as percentage of GE intake, significant differences were found $(P<0.05)$. Energy lost as feces was $30 \%$ and $35 \%$ for CON and LRS, respectively. Those values were similar to those found by Aguilera et al. (1990) with lactating Granadina goats fed alfalfa hay and barley (32\%) and by Tovar-Luna et al. (2010) with Alpine goat at mid-lactation fed $60 \%$ concentrate. Urine energy was $3.1 \%$ and $4.6 \%$ for CON and LRS, respectively, which for $\mathrm{CON}$ was comparable with the findings of Aguilera et al. (1990) and Tovar-Luna et

Table 4. Daily energy partitioning $\left(\mathrm{kJ} / \mathrm{kg}\right.$ of $\left.\mathrm{BW}^{0.75}\right)$ of MurcianoGranadina goats $(\mathrm{n}=10)$ during mid-lactation according to type of diet

\begin{tabular}{|c|c|c|c|c|}
\hline \multirow[b]{2}{*}{ Item $^{1}$} & \multicolumn{2}{|c|}{ Diet $^{2}$} & \multirow[b]{2}{*}{ SEM } & \multirow[b]{2}{*}{$P$-value } \\
\hline & $\mathrm{CON}$ & LRS & & \\
\hline $\mathrm{BW}, \mathrm{kg}$ & 47.4 & 47.3 & 0.44 & 0.84 \\
\hline DMI, $\mathrm{g} / \mathrm{kg}$ of $\mathrm{BW}^{0.75}$ & 110 & 112 & 1.6 & 0.40 \\
\hline \multicolumn{5}{|l|}{$\mathrm{kJ} / \mathrm{kg}$ of $\mathrm{BW}^{0.75}$} \\
\hline GEI & 1,913 & 1,939 & 26.7 & 0.62 \\
\hline$E_{\text {feces }}$ & 580 & 680 & 14.0 & 0.001 \\
\hline $\mathrm{DE}$ & 1,334 & 1,260 & 28.5 & 0.14 \\
\hline $\mathrm{E}_{\text {urine }}$ & 59 & 90 & 3.8 & 0.001 \\
\hline $\mathrm{E}_{\text {methane }}$ & 95 & 75 & 2.0 & 0.001 \\
\hline MEI & 1,180 & 1,095 & 18.9 & 0.023 \\
\hline HP & 596 & 572 & 6.1 & 0.07 \\
\hline $\mathrm{E}_{\text {milk }}$ & 402 & 444 & 15.2 & 0.18 \\
\hline $\mathrm{RE}$ & 585 & 523 & 9.9 & 0.021 \\
\hline $\mathrm{TE}$ & 183 & 79 & 2.4 & 0.001 \\
\hline $\mathrm{kls}$ & 0.65 & 0.63 & 0.010 & 0.023 \\
\hline \multicolumn{5}{|l|}{$\mathrm{MJ} / \mathrm{d}$} \\
\hline GEI & 35 & 35 & 0.6 & 0.22 \\
\hline $\mathrm{DE}$ & 24 & 23 & 0.4 & 0.23 \\
\hline MEI & 21 & 20 & 0.4 & 0.021 \\
\hline \multicolumn{5}{|l|}{$\%$ of GEI } \\
\hline $\mathrm{E}_{\text {feces }}$ & 30.3 & 35.0 & 0.59 & 0.009 \\
\hline $\mathrm{E}_{\text {urine }}$ & 3.08 & 4.64 & 0.073 & 0.038 \\
\hline $\mathrm{E}_{\text {methane }}$ & 4.97 & 3.87 & 0.085 & 0.049 \\
\hline $\mathrm{HP}$ & 31.1 & 29.5 & 0.54 & 0.09 \\
\hline $\mathrm{E}_{\text {milk }}$ & 21.0 & 22.9 & 0.39 & 0.047 \\
\hline $\mathrm{RE}$ & 30.6 & 27.0 & 0.52 & 0.015 \\
\hline $\mathrm{TE}$ & 9.5 & 4.1 & 0.12 & 0.001 \\
\hline $\mathrm{DE}$ & 69.7 & 65.0 & 1.21 & 0.037 \\
\hline $\mathrm{ME}$ & 61.7 & 56.5 & 1.06 & 0.012 \\
\hline \multicolumn{5}{|l|}{$\mathrm{MJ} / \mathrm{kg}$ of DM } \\
\hline $\mathrm{GE}$ & 17 & 17 & 0.3 & 0.76 \\
\hline DE & 12 & 11 & 0.2 & 0.46 \\
\hline $\mathrm{ME}$ & 11 & 10 & 0.2 & 0.43 \\
\hline NE & 7 & 6 & 0.2 & 0.43 \\
\hline
\end{tabular}

${ }^{1} \mathrm{GEI}=$ gross energy intake; $\mathrm{E}_{\mathrm{feces}}=$ energy losses in feces; $\mathrm{E}_{\text {urine }}=$ energy losses in urine; $\mathrm{E}_{\text {methane }}=$ energy losses in methane; $\mathrm{MEI}=$ metabolizable energy intake; $\mathrm{HP}=$ heat production; $\mathrm{E}_{\text {milk }}=$ recovered energy in milk; $\mathrm{RE}=$ recovered energy $(\mathrm{RE}=\mathrm{MEI}-\mathrm{HP})$; $\mathrm{TE}=$ tissue energy $\left(\mathrm{TE}=\mathrm{RE}-\mathrm{E}_{\text {milk }}\right) ; \mathrm{kls}=\mathrm{ME}$ efficiency for milk production according to INRA (2018); DE = digestible energy; NE = net energy. ${ }^{2} \mathrm{CON}=$ control; LRS $=$ lemon leaves and rice straw. al. (2010). The slightly greater urine energy with LRS might have been due to catabolism of body protein as energy source, coupled with excretion of urea in urine (Maltz and Silanikove, 1996). Heat production, as a percentage of GE intake, did not differ between diets, but digestible energy, ME, milk energy, and tissue energy were greater in CON relative to LRS. In spite of the differences, the positive tissue balance indicated that goats utilized available energy to build or deposit tissue in mid-lactation. The average energy lost from feces, heat, urine, and $\mathrm{CH}_{4}$ averaged 33, 31, 4, and $4 \%$ of GE, respectively, similar to historical data of Flatt et al. (1967) in dairy cattle. No differences between diets were detected for ME and NE when expressed per kilogram of DM; thus, average values were $10 \mathrm{MJ}$ of $\mathrm{ME} / \mathrm{kg}$ of DM and $7 \mathrm{MJ}$ of net energy $/ \mathrm{kg}$ of DM.

The proportional contribution to HPx due to oxidation of nutrients is shown in Table 5. Diet had no effect on $\mathrm{HPx}\left(572 \mathrm{~kJ} / \mathrm{kg}\right.$ of $\mathrm{BW}^{0.75}$, on average). The oxidation of nutrients, as oxidation of protein, was $6 \%$ greater $(P<0.05)$ in LRS compared with CON, which agrees with the greater energy losses (Table 4) and N excreted in urine (Table 6). It is possible that protein metabolism supported the greater milk energy (Table 4). The OXCHO increased $(P<0.05)$ from 24 to $32 \%$ in LRS and CON, respectively. No effect on OXF was detected ( $52 \%$ on average). A significant difference $(P$ $<0.05)$ was observed for RQnpx, which was significantly lower for LRS (0.79) compared with CON (0.82). Chwalibog et al. (1997) reported that RQnpx lower than 1 indicates predominance of OXF compared with $\mathrm{OXCHO}$, as was observed in this study.

Table 5. Daily energy partitioning $\left(\mathrm{kJ} / \mathrm{kg}\right.$ of $\mathrm{BW}^{0.75}$ ) of MurcianoGranadina goats $(\mathrm{n}=10)$ during mid-lactation according to type of diet

\begin{tabular}{|c|c|c|c|c|}
\hline \multirow[b]{2}{*}{ Item $^{1}$} & \multicolumn{2}{|c|}{ Diet $^{2}$} & \multirow[b]{2}{*}{ SEM } & \multirow[b]{2}{*}{$P$-value } \\
\hline & $\mathrm{CON}$ & LRS & & \\
\hline $\mathrm{HPx}$ & 582 & 562 & 5.9 & 0.100 \\
\hline $\mathrm{HPf}$ & 13.1 & 10.2 & 0.77 & 0.06 \\
\hline OXP & 95.1 & 124 & 5.56 & 0.009 \\
\hline OXCHO & 193 & 142 & 10.1 & 0.017 \\
\hline OXF & 294 & 296 & 6.7 & 0.96 \\
\hline OXP/HPx & 16.4 & 22.3 & 1.06 & 0.005 \\
\hline $\mathrm{OXCHO} / \mathrm{HPx}$ & 32.4 & 24.4 & 1.54 & 0.013 \\
\hline OXF/HPx & 51.2 & 53.2 & 1.40 & 0.57 \\
\hline RQnpx & 0.82 & 0.79 & 0.005 & 0.022 \\
\hline
\end{tabular}

${ }^{1} \mathrm{HPx}=$ heat production from oxidation of nutrients; HPf $=$ heat production of fermentation $[\mathrm{HPf}=$ heat production $-\mathrm{HPx}$ (Brouwer, 1958)]; OXP = heat production associated with oxidation of protein; $\mathrm{OXCHO}=$ heat production associated with oxidation of carbohydrates; OXF = heat production associated with oxidation of fat; RQnpx $=$ nonprotein respiratory quotient from oxidation of nutrients $\left\{\left[\mathrm{CO}_{2 \mathrm{x}}-\left(\mathrm{N}_{\text {urine }} \times 6.25 \times 0.774\right)\right] /\left[\mathrm{O}_{2}-\left(\mathrm{N}_{\text {urine }} \times 6.25 \times 0.957\right)\right]\right.$, where $\mathrm{CO}_{2 \mathrm{x}}=\mathrm{CO}_{2}$ production from oxidation and $\mathrm{N}_{\text {urine }}=\mathrm{N}$ in urine $\}$.

${ }^{2} \mathrm{CON}=$ control; $\mathrm{LRS}=$ lemon leaves and rice straw. 
Table 6. Carbon and nitrogen balance $\left(\mathrm{g} / \mathrm{kg}\right.$ of $\left.\mathrm{BW}^{0.75}\right)$ of MurcianoGranadina goats $(\mathrm{n}=10)$ during mid-lactation according to type of diet

\begin{tabular}{|c|c|c|c|c|}
\hline \multirow[b]{2}{*}{ Item $^{1}$} & \multicolumn{2}{|c|}{ Diet $^{2}$} & \multirow[b]{2}{*}{ SEM } & \multirow[b]{2}{*}{$P$-value } \\
\hline & $\mathrm{CON}$ & LRS & & \\
\hline $\mathrm{C}_{\text {intake }}$ & 46.0 & 46.4 & 0.65 & 0.75 \\
\hline $\mathrm{C}_{\text {feces }}$ & 15.2 & 18.0 & 0.37 & 0.002 \\
\hline $\mathrm{C}_{\text {urine }}$ & 1.45 & 2.13 & 0.091 & 0.001 \\
\hline $\mathrm{C}_{\mathrm{CO} 2}$ & 15.8 & 14.5 & 0.22 & 0.004 \\
\hline $\mathrm{C}_{\mathrm{CH} 4}$ & 1.31 & 1.03 & 0.028 & 0.001 \\
\hline C excretion & 33.8 & 35.7 & 0.52 & 0.06 \\
\hline $\mathrm{C}_{\text {milk }}$ & 8.00 & 8.82 & 0.302 & 0.18 \\
\hline $\mathrm{C}_{\text {body retained }}$ & 4.23 & 1.92 & 0.505 & 0.021 \\
\hline $\mathrm{N}_{\text {intake }}$ & 2.80 & 2.98 & 0.044 & 0.06 \\
\hline $\mathrm{N}_{\text {feces }}$ & 0.92 & 0.86 & 0.019 & 0.07 \\
\hline $\mathrm{N}_{\text {urine }}$ & 0.83 & 1.08 & 0.048 & 0.009 \\
\hline $\mathrm{N}$ excretion & 1.75 & 1.93 & 0.055 & 0.10 \\
\hline $\mathrm{N}_{\text {milk }}$ & 0.64 & 0.69 & 0.023 & 0.32 \\
\hline $\mathrm{N}_{\text {body retained }}$ & 0.41 & 0.36 & 0.051 & 0.56 \\
\hline $\mathrm{R}_{\text {protein }}, \mathrm{g} / \mathrm{d}$ per goat & 47.1 & 39.7 & 5.63 & 0.45 \\
\hline $\mathrm{R}_{\text {fat }}, \mathrm{g} / \mathrm{d}$ per goat & 65.9 & 16.3 & 10.26 & 0.015 \\
\hline
\end{tabular}

${ }^{1} \mathrm{C}_{\text {intake }}=\mathrm{C}$ intake; $\mathrm{C}_{\text {feces }}=\mathrm{C}$ losses in feces; $\mathrm{C}_{\text {urine }}=\mathrm{C}$ losses in urine; $\mathrm{C}_{\mathrm{CO} 2}=\mathrm{C}$ losses in $\mathrm{CO}_{2} ; \mathrm{C}_{\mathrm{CH} 4}=\mathrm{C}$ losses in methane; $\mathrm{C}_{\text {milk }}=$ recovered $\mathrm{C}$ in milk; $\mathrm{C}_{\text {body retained }}=$ recovered $\mathrm{C}$ in tissue; $\mathrm{N}_{\text {intake }}=\mathrm{N}$ intake; $\mathrm{N}_{\text {feces }}$ $=\mathrm{N}$ losses in feces; $\mathrm{N}_{\text {urine }}=\mathrm{N}$ losses in urine; $\mathrm{N}_{\text {milk }}=$ recovered $\mathrm{N}$ in milk; $\mathrm{N}_{\text {body retained }}=$ recovered $\mathrm{N}$ in tissue; $\mathrm{R}_{\text {protein }}=$ protein retained, in grams; $\mathrm{R}_{\text {fat }}=$ fat retained, in grams.

${ }^{2} \mathrm{CON}=$ control; LRS $=$ lemon leaves and rice straw.

\section{Carbon and Nitrogen Balance}

The daily $\mathrm{C}$ and $\mathrm{N}$ balance and the calculated tissue recovered as protein and fat are displayed in Table 6 . No significant differences were observed in C intake and $\mathrm{C}$ in milk. Following the trend observed for intake and apparent digestibility, the levels of $\mathrm{C}$ in feces and urine were 2.8 and $0.7 \mathrm{~g} / \mathrm{kg}$ of $\mathrm{BW}^{0.75}$ greater in LRS than in CON, respectively. The losses in $\mathrm{C}$ from $\mathrm{CO}_{2}$ and $\mathrm{CH}_{4}$ were significantly lower for LRS compared with CON (1.3 vs. $0.3 \mathrm{~g} / \mathrm{kg}$ of $\mathrm{BW}^{0.75}$, respectively) due to lower $\mathrm{CH}_{4}$ production with this diet (see Table 9). The efficiency of milk $\mathrm{C}$ output relative to $\mathrm{C}$ ingested was $18 \%$ on average.
Regardless of diet, goats ingested $\left(2.89 \mathrm{~g} / \mathrm{kg}\right.$ of BW ${ }^{0.75}$, on average) and excreted similar amounts of $\mathrm{N}$ in feces $\left(0.89 \mathrm{~g} / \mathrm{kg}\right.$ of $\mathrm{BW}^{0.75}$, on average). No differences were observed in milk $\mathrm{N}$ and $\mathrm{N}$ retained in the body, whereas greater excretion $(P=0.009)$ in urine $\mathrm{N}$ was detected for LRS than for CON $\left(0.3 \mathrm{~g} / \mathrm{kg}\right.$ of $\left.\mathrm{BW}^{0.75}\right)$. The ratio between milk $\mathrm{N}$ output and $\mathrm{N}$ ingested averaged $23 \%$. Similar to the present study, Kebreab et al. (2010) reported a reduction in urinary $\mathrm{N}$ output in dairy cows when ME intake increased. The values of $\mathrm{N}$ retained in the body were converted to grams of protein, and from this and the $\mathrm{C}$ balance value, grams of fat retained were calculated. No differences were detected between diets for protein retention. However, energy balance was 104 $\mathrm{kJ} / \mathrm{kg}$ of $\mathrm{BW}^{0.75}$ greater in CON than in LRS; thus, the fat retained was approximately $50 \mathrm{~g}$ /animal greater in CON than in LRS (Table 6).

\section{Milk Production, Fatty Acids, and Metabolites}

Diet had no effect on milk yield, which averaged 2.27 $\mathrm{kg} / \mathrm{d}$ across the 2 diets (Table 7 ). Because the main objective was to evaluate the effects of waste by-products on performance using a balanced diet, replacement of barley grain with lemon leaves and rice straw was not on a 1-to-1 basis. Rather, different ingredients were combined and soybean oil added to the LRS diet to reach the same energy and protein density as CON. Chilliard et al. (2003), in a review of the literature, concluded that fat supplementation increased milk yield in dairy cows, but not in goats, and increased milk fat content in goats, but not always in dairy cows. It would appear that the lipolytic system differs between cows and goats. The replacement of barley grain with by-products (fibrous and with higher PUFA content) increased milk fat content in LRS compared with CON (5.6 and $6.4 \%$ for CON and LRS, respectively). Thus, greater PUFA due to inclusion of soybean oil in LRS might have inhibited microbial synthesis, as reported by Chilliard et al. (2003), and also biohydrogenation.

Table 7. Daily milk production and composition of Murciano-Granadina goats $(\mathrm{n}=10)$ during mid-lactation according to type of diet

\begin{tabular}{|c|c|c|c|c|}
\hline \multirow[b]{2}{*}{ Item } & \multicolumn{2}{|c|}{$\operatorname{Diet}^{1}$} & \multirow[b]{2}{*}{ SEM } & \multirow[b]{2}{*}{$P$-value } \\
\hline & $\mathrm{CON}$ & LRS & & \\
\hline Milk yield, $\mathrm{kg} / \mathrm{d}$ per goat & 2.20 & 2.35 & 0.178 & 0.76 \\
\hline \multicolumn{5}{|l|}{ Chemical composition, $\%$} \\
\hline DM & 15.1 & 16.0 & 0.22 & 0.034 \\
\hline Fat & 5.64 & 6.43 & 0.168 & 0.015 \\
\hline Protein & 4.03 & 4.17 & 0.061 & 0.22 \\
\hline Lactose & 4.60 & 4.57 & 0.021 & 0.30 \\
\hline Nonfat dry extract & 9.46 & 9.58 & 0.071 & 0.38 \\
\hline Cheese extract & 9.68 & 10.6 & 0.212 & 0.023 \\
\hline
\end{tabular}

${ }^{1} \mathrm{CON}=$ control; LRS $=$ lemon leaves and rice straw. 
The content of FA with 16 or fewer carbon atoms derives from de novo synthesis, whereas those with 18 or more carbon atoms arise from diet or from lipid mobilization (Chilliard et al., 2003). Concentration of FA with $\mathrm{C} 11: 0$ to $\mathrm{C} 16: 1$ was greater $(P<0.05)$ in goats fed CON compared with LRS (Table 8). Fatty acids with C11:0 and C15:0 are potential biomarkers of rumen function because they are found in bacterial lipids and might be partly synthesized endogenously in the mammary gland from ruminal substrates (Vlaeminck et al., 2006; Fievez et al., 2012; Vlaeminck et al., 2015). Therefore, our data suggest better ruminal fermentation in CON than in LRS. Despite this, the greater milk fat content with LRS might have been due to PUFA content in the LRS diet plus lipolysis (i.e., recovered $\mathrm{C}$ in tissue decreased by $54 \%$ with LRS). In addition, in view of the lower protein digestibility, similar VFA content, and greater loss of $\mathrm{N}$ in urine when LRS

Table 8. Fatty acid composition (g/100 g of milk fat) of milk fat for goats fed experimental diets $(\mathrm{n}=10)$

\begin{tabular}{|c|c|c|c|c|}
\hline \multirow[b]{2}{*}{ Item $^{1}$} & \multicolumn{2}{|c|}{$\operatorname{Diet}^{2}$} & \multirow[b]{2}{*}{ SEM } & \multirow[b]{2}{*}{$P$-value } \\
\hline & $\mathrm{CON}$ & LRS & & \\
\hline $\mathrm{C} 4: 0$ & 0.62 & 0.62 & 0.016 & 0.98 \\
\hline C6:0 & 1.53 & 1.59 & 0.048 & 0.61 \\
\hline C8:0 & 2.16 & 2.28 & 0.084 & 0.46 \\
\hline C10:0 & 8.54 & 7.77 & 0.234 & 0.10 \\
\hline C11:0 & 0.26 & 0.22 & 0.013 & 0.02 \\
\hline C12:0 & 4.79 & 3.58 & 0.186 & $<0.001$ \\
\hline C14:0 & 8.74 & 7.14 & 0.275 & $<0.001$ \\
\hline $\mathrm{C} 14: 1$ & 0.16 & 0.11 & 0.010 & 0.03 \\
\hline C15:0 & 0.67 & 0.56 & 0.024 & 0.02 \\
\hline C16:0 & 25.9 & 19.3 & 1.06 & $<0.001$ \\
\hline $\mathrm{C} 16: 1$ & 0.64 & 0.44 & 0.047 & 0.03 \\
\hline $\mathrm{C} 17: 0$ & 0.37 & 0.38 & 0.038 & 0.88 \\
\hline $\mathrm{C} 17: 1$ & 0.15 & 0.13 & 0.010 & 0.23 \\
\hline C18:0 & 3.68 & 5.71 & 0.377 & 0.004 \\
\hline C18:1n-9 trans & 0.80 & 2.04 & 0.181 & $<0.001$ \\
\hline C18:1n-9 cis & 10.0 & 11.8 & 0.65 & 0.18 \\
\hline C18:1n-7 & 0.15 & 0.39 & 0.037 & $<0.001$ \\
\hline $\mathrm{C} 18: 2 \mathrm{n}-6$ trans & 0.16 & 0.23 & 0.011 & $<0.001$ \\
\hline $\mathrm{C} 18: 2 \mathrm{n}-6$ cis & 2.57 & 2.69 & 0.142 & 0.70 \\
\hline $\mathrm{C} 20: 0$ & 0.09 & 0.11 & 0.005 & 0.03 \\
\hline C18:3n-6 & 0.01 & 0.01 & 0.002 & 0.22 \\
\hline C20:1 & 0.04 & 0.03 & 0.006 & 0.51 \\
\hline C18:3n-3 & 0.57 & 0.45 & 0.054 & 0.28 \\
\hline CLA cis-9,trans-11 & 0.41 & 0.88 & 0.068 & $<0.001$ \\
\hline CLA trans-9,cis-11 & 0.04 & 0.06 & 0.003 & $<0.001$ \\
\hline CLA cis-9,cis-11 & 0.00 & 0.01 & 0.001 & $<0.001$ \\
\hline CLA trans-9,trans-11 & 0.02 & 0.04 & 0.003 & $<0.001$ \\
\hline $\mathrm{C} 20: 2$ & 0.01 & 0.01 & 0.002 & 0.23 \\
\hline $\mathrm{C} 22: 0$ & 0.03 & 0.03 & 0.003 & 0.30 \\
\hline C20:3n-6 & 0.01 & 0.01 & 0.001 & 0.61 \\
\hline C20:4n-6 & 0.14 & 0.11 & 0.007 & 0.01 \\
\hline $\mathrm{C} 22: 2$ & 0.01 & 0.11 & 0.004 & 0.72 \\
\hline C24:0 & 0.08 & 0.12 & 0.028 & 0.44 \\
\hline C20:5n-3 EPA & 0.06 & 0.02 & 0.011 & 0.08 \\
\hline Total VFA & 73.4 & 69.1 & 1.862 & 0.09 \\
\hline Short-chain fatty acids & 4.31 & 4.49 & 0.143 & 0.56 \\
\hline Medium-chain fatty acids & 13.6 & 11.6 & 0.39 & 0.01 \\
\hline Long-chain fatty acids & 55.5 & 52.9 & 1.17 & 0.27 \\
\hline Total SFA & 57.5 & 49.5 & 1.33 & $<0.001$ \\
\hline Total MUFA & 11.9 & 14.9 & 0.74 & 0.04 \\
\hline Total PUFA & 4.03 & 4.53 & 0.134 & 0.05 \\
\hline n-6 & 2.90 & 3.05 & 0.148 & 0.63 \\
\hline n-3 & 0.63 & 0.48 & 0.065 & 0.23 \\
\hline n- $6 / n-3$ ratio & 5.30 & 6.48 & 0.292 & 0.04 \\
\hline $\mathrm{TI}$ & 4.58 & 2.81 & 0.298 & $<0.001$ \\
\hline $\mathrm{AI}$ & 2.68 & 1.91 & 0.121 & $<0.001$ \\
\hline
\end{tabular}


Table 9. Methane emission of Murciano-Granadina goats $(\mathrm{n}=10)$ during mid-lactation according to type of diet

\begin{tabular}{|c|c|c|c|c|}
\hline \multirow[b]{2}{*}{ Item $^{1}$} & \multicolumn{2}{|c|}{$\operatorname{Diet}^{2}$} & \multirow[b]{2}{*}{ SEM } & \multirow[b]{2}{*}{$P$-value } \\
\hline & $\mathrm{CON}$ & LRS & & \\
\hline $\mathrm{CH}_{4}, \mathrm{~g} / \mathrm{d}$ & 31.1 & 24.3 & 0.64 & 0.001 \\
\hline $\mathrm{Ym}, \%$ & 4.47 & 3.87 & 0.085 & 0.001 \\
\hline $\mathrm{CH}_{4} / \mathrm{DMI}, \mathrm{g} / \mathrm{kg}$ & 15.6 & 12.0 & 0.33 & 0.001 \\
\hline $\mathrm{CH}_{4} / \mathrm{DMd}, \mathrm{g} / \mathrm{kg}$ & 22.9 & 18.9 & 0.55 & 0.001 \\
\hline $\mathrm{CH}_{4} / \mathrm{OMi}, \mathrm{g} / \mathrm{kg}$ & 16.8 & 13.3 & 0.35 & 0.001 \\
\hline $\mathrm{CH}_{4} / \mathrm{OMd}, \mathrm{g} / \mathrm{kg}$ & 23.9 & 20.2 & 0.55 & 0.001 \\
\hline $\mathrm{CH}_{4} / \mathrm{NDFd}, \mathrm{g} / \mathrm{kg}$ & 61.7 & 67.7 & 1.89 & 0.001 \\
\hline $\mathrm{CH}_{4} /$ cheese extract, $\mathrm{g} / \mathrm{kg}$ & 152 & 119 & 3.9 & 0.001 \\
\hline $\mathrm{CH}_{4} / \mathrm{milk}, \mathrm{g} / \mathrm{kg}$ & 14.1 & 10.4 & 0.38 & 0.008 \\
\hline
\end{tabular}

was fed, we speculate that the lack of response in milk protein with this diet was partly due to a reduction in mammary supply of essential amino acids.

In our study, C16:0 was $6.56 \mathrm{~g} / 100 \mathrm{~g}$ greater in goats fed CON compared with LRS (Table 8). Milk C16:0 results mainly from de novo FA synthesis in mammary tissue using acetate produced in the rumen during fiber digestion, with $\mathrm{CH}_{4}$ output positively correlated with milk C16:0 (Fievez et al., 2012). Greater values $(P<$ 0.05) of C18:0, C18:1, C18:2, and CLA were detected in response to feeding LRS compared with CON. The increase in C18:0 and CLA with LRS were probably associated with greater intake of PUFA and, therefore, greater rate of biohydrogenation (Table 2 shows FA profiles of CON and LRS diets). Fernández et al. (2018) reported that lemon leaves contain $3 \% \mathrm{EE}$, with high concentrations of C18:1n-9 cis, C18:2n-6 cis, and C18: 3n-3, which are known for their antibacterial activities (Desbois and Smith, 2010). Atherogenicity and thrombogenic indices were calculated as indicated by Ulbricht and Southgate (1991), and from a human health standpoint the lower index of LRS compared with CON suggested higher quality.

Elevated concentrations of free amino groups and glutamate were detected in ruminal fluid in response to feeding LRS compared with CON (Supplemental Table S1, https://doi.org/10.3168/jds.2020-18168). This was accompanied by greater concentrations of protein and urea $(P<0.05)$. In urine, compared with $\mathrm{CON}$, feeding LRS led to higher levels of protein, free amino groups, glutamate, ammonium, urea, and uric acid. Consistent with data from other authors (Bjerre-Harpøth et al., 2012), levels of negative energy indicators (BHB and isocitrate) were in the normal range for both groups. Although free amino groups were greater in the LRS group, no marked differences were observed for milk indicators of ruminal $\mathrm{N}$ flow such as uric acid and urea in milk.

\section{Methane Emissions}

The reduction in $\mathrm{CH}_{4}$ with LRS was partly caused by decreasing overall carbohydrate digestion. Compared with the CON $\operatorname{diet}(31.1 \mathrm{~g} / \mathrm{d})$, goats fed LRS produced significantly $(P<0.05)$ fewer $\mathrm{CH}_{4}$ emissions $(24.3 \mathrm{~g} / \mathrm{d}$; Table 9), a response that agrees with the fact that FA have a strong inhibitory effect on protozoa and cellulolytic bacteria that can cause shifts in fermentation patterns that reduce $\mathrm{CH}_{4}$ production. In addition to the known negative effects of PUFA on $\mathrm{CH}_{4}$ production via direct toxic effects on ruminal microorganisms and protozoa (Newbold et al., 1995), as discussed previously (Fernández et al., 2019b), secondary compounds such as tannins and essential oils from lemon leaves in the LRS diet also explain the mitigation of $\mathrm{CH}_{4}$ observed with this diet. Therefore, although the reduction in $\mathrm{CH}_{4}$ averaged $22 \%$, differences in fat percentage between CON and LRS averaged $2 \%$. Thus, each percentage of increase in fat was associated with average reductions of 4 to $5 \%$ in $\mathrm{CH}_{4}$ (Patra, 2014). Clearly, much higher $\mathrm{CH}_{4}$ inhibition in this study might result from other secondary metabolite components such as essential oils and tannins present in leaves. Further research should be performed to better understand how secondary compounds in citrus residue directly influence ruminal microorganisms.

Because ruminants lose between 2 and $12 \%$ of their dietary $\mathrm{GE}$ as $\mathrm{CH}_{4}$, a decrease in production of $\mathrm{CH}_{4}$ represents an improvement in feed efficiency (Johnson and Johnson, 1995). The ratios of $\mathrm{CH}_{4}$ energy loss per unit of GE intake were 4.47 and $3.87 \%$ for CON and LRS, respectively $(P<0.05)$. The greater lipid content of LRS and its FA profile (Tables 1 and 8) probably had negative effects on methanogens and fiber degradation, which was reflected in lower NDF and ADF digestibility (Table 2). Although $\mathrm{CH}_{4}$ emission is most commonly expressed in the literature relative to GE 
intake, the most meaningful expression is relative to DM or OM intakes. In the present work, when $\mathrm{CH}_{4}$ was expressed relative to DM and OM intake or digested, statistical differences $(P<0.05)$ remained. In addition, goats fed LRS produced less $\mathrm{CH}_{4}$, because the amount of NDF digested was lower. Furthermore, feeding LRS reduced the amount of $\mathrm{CH}_{4}$ by $3.8 \mathrm{~g} / \mathrm{kg}$ of milk. Patra et al. (2017) reported that some plant secondary metabolites may exert inhibitory effects on methanogenic activity, and lemon leaves contain essential oils and tannins. Thus, further research should be performed to better understand how secondary compounds in citrus residue directly affect ruminal microorganisms.

\section{CONCLUSIONS}

The replacement of $41 \%$ of barley grain with lemon leaves $(19 \%$, higher essential oil content and plant secondary metabolites than barley grain), rice straw $(12 \%)$, and soybean oil $(1.9 \%)$ in the concentrate fed to dairy goats did not affect DMI and milk production. Although MEI was reduced from 21 to $20 \mathrm{MJ} / \mathrm{d}$, milk fat yield increased (from 5.64 to $6.43 \%$ ), whereas methane emissions decreased (22\%). Milk C16:0 decreased, and increases in CLA and linoleic acid occurred. Thus, inclusion of these by-products into compound feeds fed to small ruminants appears warranted. It could elicit multiple positive effects, as on the efficiency of nutrient use, human health, and the environment.

\section{ACKNOWLEDGMENTS}

This study was supported by LIFE Project, Valencia, Spain (ref. LIFE2016/CCM/ES/000088 LOW CARBON FEED). The authors have not stated any conflicts of interest.

\section{REFERENCES}

Aguilera, J. F., and C. Prieto. 1986. Description and function of an open-circuit respiration plant for pigs and small ruminants and the techniques used to measure energy metabolism. Arch. Tierernahr. 36:1009-1018. https://doi.org/10.1080/17450398609429522.

Aguilera, J. F., C. Prieto, and J. Fonollá. 1990. Protein and energy metabolism of lactating Granadina goats. Br. J. Nutr. 63:165-175. https://doi.org/10.1079/BJN19900104.

AOAC International. 2000. Official Methods of Analysis of the Association of Official Analytical Chemists. 18th ed. Association of Official Analytical Chemists, Arlington, VA.

Bampidis, V. A., and P. H. Robinson. 2006. Citrus by-products as ruminant feeds: A review. Anim. Feed Sci. Technol. 128:175-217. https://doi.org/10.1016/j.anifeedsci.2005.12.002.

Batey, I. L. 1982. Starch analysis using thermostable $\alpha$-amylases. Stach/Stärke 34:125-128.

Bjerre-Harpøth, V., N. C. Friggens, V. M. Thorup, T. Larsen, B. M. Damgaard, K. L. Ingvartsen, and K. M. Moyes. 2012. Metabolic and production profiles of dairy cows in response to decreased nutrient density to increase physiological imbalance at different stages of lactation. J. Dairy Sci. 95:2362-2380. https://doi.org/10 $.3168 /$ jds.2011-4419.

Brockway, J. M., A. W. Boyne, and J. G. Gordon. 1971. Simultaneous calibration of gas analyzers and meters. J. Appl. Physiol. 31:296297. https://doi.org/10.1152/jappl.1971.31.2.296.

Brouwer, E. 1958. On simple formulae for calculating the heat expenditure and the quantities of carbohydrate and fat metabolized in ruminants, from data on gaseous exchange and urine N. Pages 182-194 in Proc. 1st Symposium on Energy Metabolism. EAAP. Publ. 8. Academic Press, London.

Brouwer, E. 1965. Report of sub-committee on constants and factors. In: Blaxter, K.L. (Ed.), Pages 441-443 in Proc. of the 3th Symposium on Energy Metabolism. EAAP Publ. 11. Academic Press, London.

Calsamiglia, S., A. Bach, C. de Blas, C. Fernández, and P. GarcíaRebollar. 2009. Nutritional requirements for dairy ruminants. Fundación Española para el Desarrollo de la Nutrición Animal (FEDNA), Madrid, Spain.

Calsamiglia, S., M. Busquet, P. W. Cardozo, L. Castillejos, and A. Ferret. 2007. Invited review: Essential oils as modifiers of rumen microbial fermentation. J. Dairy Sci. 90:2580-2595. https://doi .org/10.3168/jds.2006-644.

Casper, D. P., H. A. Maiga, M. J. Brouk, and D. J. Schingoethe. 1999. Synchronization of carbohydrate and protein sources on fermentation and passage rates in dairy cows. J. Dairy Sci. 82:1779-1790. https://doi.org/10.3168/jds.S0022-0302(99)75408-1.

Chilliard, Y., A. Ferlay, J. Rouel, and G. Lamberet. 2003. A review and nutritional and physiological factors affecting goat milk lipids synthesis and lipolysis. J. Dairy Sci. 86:1751-1770. https://doi .org/10.3168/jds.S0022-0302(03)73761-8.

Chwalibog, A., A. H. Tauson, and G. Thorbek. 1997. Quantitative oxidation of nutrients in growing calves. Z. Ernahrungswiss. 36:313316. https://doi.org/10.1007/BF01617806.

Desbois, A. P., and V. J. Smith. 2010. Antibacterial free fatty acids: Activities, mechanisms of action and biotechnological potential. Appl. Microbiol. Biotechnol. 85:1629-1642.

EFEAGRO. 2016. EFE agency for the Agrifood Sector, Campaña Citrícola, Madrid, Spain. Accessed Oct. 10, 2016. http://efeagro $. \mathrm{com} /$.

European Union. 2003. Protection of animals used for experimental purposes. Council Directive 86/609/EEC of 24 November 1986 , amended 16.9.2003. European Council, Brussels, Belgium.

Fahey, G. C., and L. L. Berger. 1988. Carbohydrate nutrition of ruminants. Pages 269-297 in The Ruminant Animal: Digestive Nutrition and Physiology. D. C. Church, ed. Prentice-Hall, Englewood Cliffs, NJ.

FAOSTAT. 2019. European Commission Data Base. Agriculture, forestry and fisheries. Accessed July 22, 2019. http://ec.europa.eu/ eurostat/data/database.

Fernández, C., J. Gomis-Tena, A. Hernández, and J. Saiz. 2019a. An open-circuit indirect calorimetry head hood system for measuring methane emissions and energy metabolism in small ruminants. Animals (Basel) 9:E380. https://doi.org/10.3390/ani9060380.

Fernández, C., M. C. López, and M. Lachica. 2012. Description and function of a mobile open-circuit respirometry system to measure gas exchange in small ruminants. Anim. Feed Sci. Technol. 172:242-246. https://doi.org/10.1016/j.anifeedsci.2012.01.006.

Fernández, C., M. C. López, and M. Lachica. 2015. Low cost mobile open-circuit hood system for measuring gas exchange in small ruminants: From manual to automatic recording. J. Agric. Sci. 153:1302-1309. https://doi.org/10.1017/S0021859615000416.

Fernández, C., J. V. Martí, I. Pérez-Baena, J. L. Palomares, C. Ibáñez, and J. V. Segarra. 2018. Effect of lemon leaves on energy and CN balances, methane emission, and milk performance in MurcianoGranadina dairy goats. J. Anim. Sci. 96:1508-1518. https://doi .org/10.1093/jas/sky028.

Fernández, C., I. Pérez-Baena, J. V. Martí, J. L. Palomares, J. JorroRipoll, and J. V. Segarra. 2019b. Use of orange leaves as a replacement for alfalfa in energy and nitrogen partitioning, methane emissions and milk performance of Murciano-Granadina goats. 
Anim. Feed Sci. Technol. 247:103-111. https://doi.org/10.1016/j anifeedsci.2018.11.008.

Fievez, V., E. Colman, J. M. Castro-Montoya, I. Stefanov, and B. Vlaeminck. 2012. Milk odd- and branched-chain fatty acids as biomarkers of rumen function: An update. Anim. Feed Sci. Technol. 172:51-65. https://doi.org/10.1016/j.anifeedsci.2011.12.008.

Flatt, W. P., P. W. Moe, and R. R. Oltjen. 1967. Energy metabolism studies with dairy cows receiving purified diets. Pages 109-121 in Energy Metabolism of Farm Animals, Proc 4th Symp. Energy Metab. Warsaw, Poland. K. L. Blaxter, ed. Academic Press, London, UK.

Harano, Y., M. Ohtsuki, M. Ida, H. Kojima, M. Harada, T. Okanishi, A. Kashiwagi, Y. Ochi, S. Uno, and Y. Shigeta. 1985. Direct automated assay method for serum or urine levels of ketone bodies. Clin. Chim. Acta 151:177-183. https://doi.org/10.1016/0009 -8981(85)90321-3.

INRA. 2018. INRA Feeding System for Ruminants. Wageningen Academic Publishers, Wageningen. the Netherlands.

Johnson, K. A., and D. E. Johnson. 1995. Methane emissions in cattle. J. Anim. Sci. 73:2483-2492. https://doi.org/10.2527/1995 $.7382483 \mathrm{x}$

Jouany, J. P. 1982. Volatile fatty acid and alcohol determination in digestive contents, silage juices, bacterial cultures and anaerobic fermentor contents. Sci. Aliments 2:131-144.

Kebreab, E., A. B. Strathe, J. Dijkstra, J. A. N. Mills, C. K. Reynolds, L. A. Crompton, T. Yan, and J. France. 2010. Energy and protein interactions and their effects on nitrogen excretion in dairy cows. Pages 417-426 in Symp. on Energy and Protein Metabolism and Nutrition, Parma, Italy.

Knapp, J. R., G. L. Laur, P. A. Vadas, W. P. Weiss, and J. M. Tricarico. 2014. Invited review: Enteric methane in dairy cattle production: Quantifying the opportunities and impact of reducing emissions. J. Dairy Sci. 97:3231-3261. https://doi.org/10.3168/jds .2013-7234.

Larsen, T. 2014. Fluorometric determination of free and total isocitrate in bovine milk. J. Dairy Sci. 97:7498-7504. https://doi.org/ 10.3168/jds.2014-8018.

Larsen, T. 2015. Fluorometric determination of free glucose and glucose 6-phosphate in cow's milk and other opaque matrices. Food Chem. 166:283-286. https://doi.org/10.1016/j.foodchem.2014.06 .017 .

Larsen, T., and C. Fernández. 2017. Enzymatic-fluorometric analyses for glutamine, glutamate and free amino groups in protein-free plasma and milk. J. Dairy Res. 84:32-35. https://doi.org/10.1017/ S0022029916000789.

Larsen, T., and K. M. Moyes. 2010. Fluorometric determination of uric acid in bovine milk. J. Dairy Res. 77:438-444. https://doi.org/10 $.1017 /$ S0022029910000580

Larsen, T., and N. I. Nielsen. 2005. Fluorometric determination of $\beta$-hydroxybutyrate in milk and blood plasma. J. Dairy Sci. 88:2004-2009. https://doi.org/10.3168/jds.S0022-0302(05)72876 -9 .

Maltz, E., and N. Silanikove. 1996. Kidney function and nitrogen balance of high yielding dairy cows at the onset of lactation. J. Dairy Sci. 79:1621-1626. https://doi.org/10.3168/jds.S0022 -0302(96) 76525-6.

McLean, J. A., and G. Tobin. 1987. Animal and Human Calorimetry. Cambridge University Press, Cambridge, UK

Mertens, D. R. 2002. Gravimetric determination of amylase-treated neutral detergent fibre in feeds with refluxing beakers or crucibles: Collaborative study. J. AOAC Int. 85:1217-1240.

National Research Council (NRC). 2001. Nutrient requirements of dairy cattle. 7th rev. ed. Natl. Acad. Press, Washington, DC.

Newbold, C. J., B. Lassalas, and J. P. Jouany. 1995. The importance of methanogens associated with ciliated protozoa in ruminal methane production in vitro. Lett. Appl. Microbiol. 21:230-234. https://doi .org/10.1111/j.1472-765X.1995.tb01048.x.

O'Fallon, J. V., J. R. Busboom, M. L. Nelson, and C. T. Gaskins. 2007. A direct method for fatty acid methyl ester synthesis: Application to wet meat tissues, oils, and feedstuffs. J. Anim. Sci. 85:1511-1521. https://doi.org/10.2527/jas.2006-491.
Ørskov, E. R., and C. Fraser. 1975. The effects of processing of barleybased supplements on rumen $\mathrm{pH}$, rate of digestion and voluntary intake of dried grass in sheep. Br. J. Nutr. 34:493-500. https://doi .org/10.1017/S0007114575000530.

Palmquist, D. L., and T. C. Jenkins. 1980. Fat in lactation rations. J. Dairy Sci. 63:1-14. https://doi.org/10.3168/jds.S0022 $-0302(80) 82881-5$.

Patra, A. 2014. A meta-analysis of the effect of dietary fat on enteric methane production, digestibility and rumen fermentation in sheep, and a comparison of these responses between cattle and sheep. Livest. Sci. 162:97-103. https://doi.org/10.1016/j.livsci .2014.01.007.

Patra, A., T. Park, M. Kim, and Z. Yu. 2017. Rumen methanogens and mitigation of methane emission by anti-methanogenic compounds and substances. J. Anim. Sci. Biotechnol. 8:13. https://doi .org/10.1186/s40104-017-0145-9.

Patra, A., and Z. Yu. 2012. Effect of essential oils on methane production and fermentation by, and abundance and diversity of, rumen microbial populations. Appl. Environ. Microbiol. 78:4271-4280. https://doi.org/10.1128/AEM.00309-12.

R Core Team. 2016. R: A Language and Environment for Statistical Computing. R Foundation for Statistical Computing, Vienna, Austria. https://www.R-project.org/.

Ramos-Morales, E., A. Arco-Pérez, A. I. Martín-García, D. R. YáñezRuiz, P. Frutos, and G. Hervás. 2014. Use of stomach tubing as an alternative to rumen cannulation to study ruminal fermentation and microbiota in sheep and goats. Anim. Feed Sci. Technol. 198:57-66. https://doi.org/10.1016/j.anifeedsci.2014.09.016.

Romero-Huelva, M., and E. Molina-Alcaide. 2013. Nutrient utilization, ruminal fermentation, microbial nitrogen flow, microbial abundances, and methane emissions in goats fed diets including tomato and cucumber waste fruits. J. Anim. Sci. 91:914-923.

Tovar-Luna, I., R. Puchala, T. Sahlu, H. C. Freetly, and A. L. Goetsch. 2010. Effects of stage of lactation and dietary concentrate level on energy utilization by Alpine dairy goats. J. Dairy Sci. 93:48184828. https://doi.org/10.3168/jds.2010-3315.

Ulbricht, T. L., and D. A. T. Southgate. 1991. Coronary heart disease: Seven dietary factors. Lancet 338:985-992. https://doi.org/ 10.1016/0140-6736(91)91846-M.

van Knegsel, A. T., H. van den Brand, J. Dijkstra, W. M. van Straalen, M. J. Heetkamp, S. Tamminga, and B. Kemp. 2007. Dietary energy source in dairy cows in early lactation: Energy partitioning and milk composition. J. Dairy Sci. 90:1467-1476. https://doi.org/ 10.3168/jds.S0022-0302(07)71632-6.

Van Soest, P. J. 2006. Rice straw, the role of silica and treatments to improve quality. Anim. Feed Sci. Technol. 130:137-171. https:// doi.org/10.1016/j.anifeedsci.2006.01.023.

Vlaeminck, B., V. Fievez, A. R. J. Cabrita, A. J. M. Fonseca, and R. J. Dewhurst. 2006. Factors affecting odd- and branched-chain fatty acids in milk: A review. Anim. Feed Sci. Technol. 131:389-417. https://doi.org/10.1016/j.anifeedsci.2006.06.017

Vlaeminck, B., R. Gervais, M. M. Rahman, F. Gadeyne, M. Gorniak, M. Doreau, and V. Fievez. 2015. Postruminal synthesis modifies the odd- and branched-chain fatty acid profile from the duodenum to milk. J. Dairy Sci. 98:4829-4840. https://doi.org/10.3168/jds 2014-9207.

Zheng, X., D. Streimikiene, T. Balezentis, A. Mardani, F. Cavallaro, and H. Liao. 2019. A review of greenhouse gas emission profiles, dynamics and climate change mitigation efforts across the key climate change players. J. Clean. Prod. 234:1113-1133. https://doi .org/10.1016/j.jclepro.2019.06.140.

\section{ORCIDS}

T. Larsen (® https://orcid.org/0000-0003-3058-5938

J. Gomis-Tena @ https://orcid.org/0000-0002-1309-2368

J. J. Loor @ https://orcid.org/0000-0003-1586-4365

C. Fernández @ https://orcid.org/0000-0002-0368-0158 